\title{
ИЗМЕНЕНИЯ КОЭФФИЦИЕНТА ПРОВОДИМОСТИ В ОКОЛОТРУБОЧНОМ ПРОСТРАНСТВЕ КИМБЕРЛИТОВОЙ ТРУБКИ «ИНТЕРНАЦИОНАЛЬНАЯ»
}

\author{
А. М. Янников \\ Воронежский государственный университет \\ АК «АЛРОСА» ПАО, г. Мирный
}

Поступила в редакцию 1 ноября 2018 г.

\begin{abstract}
Аннотация: рассматриваются гидрогеологические и гидрогеохимические данные кимберлитовмещающих (толбачанской и эльгянской свит), составляющих околотрубочное пространство коренного месторождения алмазов трубки «Интернациональная». Месторождение приурочено к юго-западной части Вилюйско-Мархинской зоны разломов (Якутская алмазоносная провинция, Мирнинское кимберлитовое поле). Приведена гидрогеологическая характеристика рассолов толбачанской и эльгянской свит, проведен анализ данных: в первом случае на основе временной закономерности дебита, во втором - по временным закономерностям приведённого понижения. По участкам графиков, отвечающих квазистационарному режиму фильтраџии, на основе графоаналитического метода рассчитано площадное распространение коэффищиента проводимости в околотрубочном массиве месторождения трубка «Интернациональная» по наблюдательным скважинам 1Д, 2Д, ЗД, 5Д, бД, 7Д, 9Д, 12Д, пробуренным в подземных горных выработках рудника «Интернациональный»на горизонте. (-790) м.

Ключевые слова: Непско-Ботуобинская антеклиза, Мирнинский выступ, месторождение трубки «Интернациональная», толбачанская свита, эльгянская свита, малодебитные трещиноватые коллектора, насыщенные рассолы, коэффициент проводимости.
\end{abstract}

\section{THE ANALYSIS OF A SQUARE DISTRIBUTION OF CONDUCTIVITY FACTOR IN COLLECTORS OF TOLBACHANSKY SUITE IN A CROSS-CUTTING MASS OF FIELD THE TUBE «INTERNATIONAL»}

\begin{abstract}
: hydrogeological and hydrogeochemical data on tolbachansky and elgyansky suites in neartubular space of the radical diamond field «International» tube, belonging to a southwest part of the Yakutskoy kimberlite province located along the Vilyuysk-Markhinsky zone of breaks where the Mirninsky diamondiferous kimberlite field is revealed are taken as a basis of article. On the basis of basic data the hydrogeological characteristic of brines tolbachansky is given and elgyansky the analysis of data is twisted, carried out: in the first case on the basis of temporary regularity of an output, in the second -- on temporary regularities of the given decrease. Also, on the basis of a graphic-analytical method, on sites of the schedules answering to the near-tubular mode of filtration vulgar distribution of coefficient of conductivity in the okolotrubochny massif of the field a tube of «International» on the observation wells $1 D$, $2 D, 3 D, 5 D, 6 D, 7 D, 9 D, 12 D$ drilled in underground excavations of the International mine on the horizon has been calculated. (-790) $\mathrm{m}$.

Keywords: Nepsko-Botuobinsky anteklise, Mirninsky ledge, field of a tube "International", tolbachansky suite, elgyansky suite, marginal jointed collector, saturated brines, conductivity coefficient.
\end{abstract}

Толбачанская свита $\left(\epsilon_{1}\right.$ tb) впервые выделена А. К. Бобровым в 1945 г. Названа по реке Толбачан - правому притоку реки Лена $[1,2]$. В стратиграфическом отношении она коррелируется с бельской свитой юга Сибирской платформы, залегает согласно на породах эльгянской свиты и перекрывается олекминской.

Коренное месторождение алмазов - трубка Интер- национальная прорывает породы нижнего палеозоя, включая толбачанскую свиту. До начала нашего века месторождение было отработано с поверхности карьером и в настоящее время ведется отработка глубоких горизонтов. При отработке шахтным способом возникают проблемы, вызванные неоднородностью вмещающих пород: трещинноватостью, газонасыщенно- 
стью и различной проводимостью. Это обусловило актуальность выполнения работ по изучению вариаций проводимости вмещающих пород, залегающих в околотрубочном пространстве.

В пределах околотрубочного пространства трубки Интернациональная глубина залегания толбачанской свиты от дневной поверхности составляет 1065,0 метров (абсолютная отметка кровли -665 м) [3].

В породах толбачанской свиты в пределах изучаемого участка выделяется пять газонасыщенных коллекторов $[4,5]$, восемь коллекторов газоводонасыщенных и два коллектора «сухих». Коллектора состоят из отдельных пластов - коллекторов мощностью от 0,4 м до 4,5 м. Эффективная общая мощность газоводонасыщенных коллекторов толбачанской свиты 91,4 м.

Пластовые воды в коллекторах данных свит высоконапорные, по химическому составу рассолы хлоридного кальциевого состава с минерализацией до 510 г/л, характеризуются кислой реакцией ( $\mathrm{pH}$ до 5,8), весьма высокими концентрациями брома, калия, стронция, лития, цинка, марганца.

Формула солевого состава:

$$
M_{440-510} \frac{C l_{99}}{C a_{62}(N a+K)_{22} M g_{16}} \operatorname{ph~5,8\gamma 1,285}
$$

Рассолы являются агрессивными к бетону и металлам по величине $\mathrm{pH}$ и содержанию магния. В составе газов решающую роль играет метан (до 95\% по объему), присутствуют тяжелые углеводороды [6, 7].

Необходимо отметить, что зона формирования и развития хлоридных кальциевых рассолов является зоной крайне затрудненного водообмена [8]. При этом водообороту препятствовали пласты практически водонепроницаемой каменной соли, вторичные выделения галита и сульфатных минералов в трещинах и порах нижнекембрийских отложений. В ходе геологического развития внутри водоупорной толщи межсолевых отложений происходили обменные процессы между водой и породой, процессы перекристаллизации отложений, реакции минералообразования в условиях изменяющихся давлений и температур, связанных с внедрением базитовых и кимберлитовых тел [9]. Эти процессы приводили к уменьшению пористости и проницаемости толщ и затрудняли водообмен. Поэтому весьма крепкие и предельно насыщенные рассолы, распространенные в межсолевых и подсолевых отложениях, являются растворами концентрирования первичной рапы седиментационного происхождения, претерпевшими определенные изменения в стадию эпигенеза.

Резкие различия в составе гидрогеохимических зон с натриевыми и кальциевыми рассолами связаны с трансформацией условий водообмена. По возрасту седиментационные хлоридные кальциевые рассолы являются кембрийскими $[10,11]$.

Главным осложняющим фактором при ведении геологоразведочных и горнодобычных работ в отложениях толбачанской свиты является наличие в коллекторах насыщенных рассолов, неструктурных залежей- ловушек углеводородных газов, а также неравномерная проницаемость пластов [12].

При анализе гидродинамического режима и проницаемости пластов-коллекторов толбачанской свиты непосредственно в околотрубочном пространстве месторождения было выделено несколько различных блоков-зон. Для выделения блоков-зон были проведены расчёты коэффициента проводимости по сети скважин, пробуренных в подземных горных выработках рудника «Интернациональный» на горизонте -790 м. Проводимость рассчитывалась по скважинам №№ 1Д, 2Д, 3Д, 5Д, 6Д, 7Д, 9Д и 12Д.

Выбранные опытные скважины являются совершенными по качеству вскрытия описанных коллекторов, поэтому полученные параметры будут в целом правомочны для изучаемого объекта (коллектора толбачанской свиты). Расположение опытных скважин относительно тела трубки «Интернациональная» приведено на рис. 1.

Определение параметра проводимости производилось в результате интерпретации одиночных выпусков пластовых вод. При выпусках для наблюдательных скважин характерно постоянство понижения с учётом переменности дебита в возмущающей скважине. По этой причине обработка опытных данных, получаемых в возмущающих и наблюдательных скважинах, производится различными способами.

В первом случае основные расчётные параметры определяются по временной закономерности дебита, во втором - по временным закономерностям приведённого понижения. Обработка опытной информации возмущающих скважин при выпуске пластовых вод производится на основе формулы:

$$
Q_{(t)}=\frac{K M * S_{0}}{0.183 * l g \frac{2.25 a t}{r_{0}^{2}}}, \text { при } \frac{a t}{r_{0}^{2}}>100, \text { где: }
$$

$\mathrm{S}_{0}$ - понижение в возмущающей скважине;

$\mathrm{r}_{0}$ - радиус возмущающей скважины.

Записывая эту формулу в виде уравнения прямой, получаем:

$$
\frac{1}{Q}=A+C * \lg t, \text { где: }
$$

$\mathrm{C}$ - угловой коэффициент графика $\frac{1}{Q}-\lg t$, откуда

$$
\mathrm{KM}=\frac{0.183}{\mathrm{C} * S_{0}}
$$

Поскольку величина $\frac{1}{Q}$ вследствие сопротивления прискважинной зоны оказывается завышенной, получение действующих величин пьезопроводности при помощи наблюдений в возмущающих скважинах не производится (по причине получения заниженных значений). Расчёты были выполнены с помощью графоаналитического метода по участкам графиков, отвечающих квазистационарному режиму фильтрации. Результаты расчётов основных гидрогеологических параметров приведены в табл. 1.

По параметру проводимости объект исследования можно представить следующим образом:

Блок-зона № 1, в которой расположены скважины 


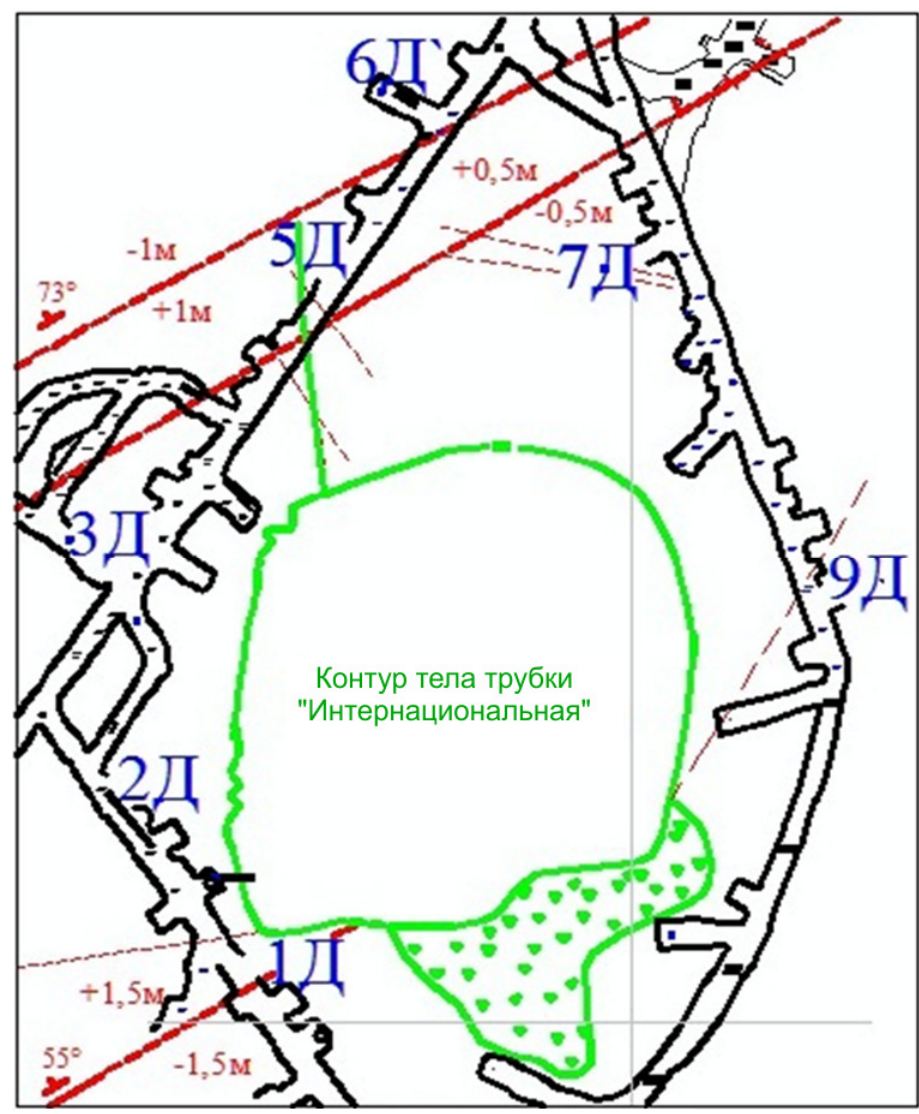

\section{УСЛОВНЫЕ ОБОЗНАЧЕНИЯ:}

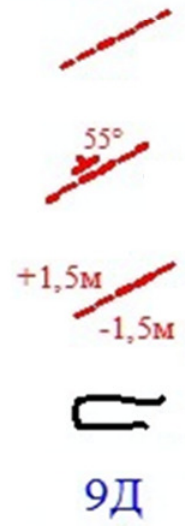

оперяющие разломы

элементы залегания разломов

амплитуда сброса/взброса

подземные горные выработки

опытные скважины (центр цифры местоположение устья скважины)

Puc 1. Расположение опытных скважин на горизонте -790 м.

Таблица 1

Полученные гидрогеологические параметры

\begin{tabular}{|c|c|c|c|}
\hline $\begin{array}{c}\text { № } \\
\text { скважины }\end{array}$ & $\begin{array}{c}\text { Расстояние } \\
\text { до «рудно- } \\
\text { го» тела, м }\end{array}$ & $\begin{array}{c}\text { Направление } \\
\text { расположения }\end{array}$ & $\begin{array}{c}\text { Полученный } \\
\text { КМ (Т), } \\
\mathrm{m}^{2} / \text { сут }\end{array}$ \\
\hline 1Д & 5 & Ю & 0,0064 \\
\hline 2Д & 15 & 3 & 0,0057 \\
\hline 3Д & 38 & 3 & 0,0180 \\
\hline 5Д & 57 & $\mathrm{C}$ & 0,0310 \\
\hline 6Д & 82 & $\mathrm{C}$ & 0,0125 \\
\hline 7Д & 43 & $\mathrm{C}$ & 0,0079 \\
\hline 9Д & 43 & $\mathrm{~B}$ & 0,0087 \\
\hline 12Д & 20 & Ю & 0,0072 \\
\hline
\end{tabular}

№o 3Д, 5Д и 6Д. Эта зона характеризуется сложным структурно-тектоническим строением, приуроченностью к малоамплитудному тектоническому нарушению, фиксируемому по наличию сближенных кимберлитовых жил, ступенчатых сбросов (до 3 метров) и флексурным перегибам слоёв и наибольшей величиной $\mathrm{KM}=0,0125-0,0310 \mathrm{~m}^{2} /$ сут.

Блок-зона № 2, в которой расположены скважины №o 7Д и 9Д, характеризует зону оперяющих разломов зафиксированного малоамплитудного тектонического нарушения. Данная зона характеризуется величиной водопроводимости КМ = 0,0079-0,0087 м²/сут;

Блок-зона № 3 изучена скважинами №№ 1Д и 12Д. Характеризуется сложным структурно- тектоническим строением, приуроченностью к малоамплитудному тектоническому нарушению, фиксируемому по наличию сближенных кимберлитовых жил, ступенчатых сбросов (до 1,5 м) и флексурным перегибам слоёв и величиной $\mathrm{KM}=0,0064-0,0072$ $\mathrm{M}^{2} /$ сут.

Блок-зона № 4 изучена скважиной № 2Д и характеризует зону, не осложнённую оперяющими разломами или малоамплитудными тектоническими нарушениями. Эта зона имеет наименьшую величину КМ $=0,0057 \mathrm{~m}^{2} /$ сут.

Проведённые исследования и выполненные расчёты позволяют сделать вывод, что проводимость коллекторов толбачанской свиты в пределах околотрубочного массива месторождения трубка «Интернациональная», на удалении 5-110 м от тела напрямую зависит от малоамплитудной тектоники, оперяющих разломов и блоковых дислокаций, непосредственно связанных со структурно-тектоническим строением изучаемого участка.

\section{ЛИТЕРАТУРА}

1. Бобров, А. К. К стратиграфии кембрия нижнего течения p. Олекмы. Материалы по геологии и полезным ископаемым Якутии / А. К. Бобров. - Тр. Якутского ФАН СССР. Сб. 4. - 1959. - 155-164 с.

2. Решение всесоюзного совещания по разработке унифицированных стратиграфических схем докембрия, палеозоя и четвертичной системы Средней Сибири. Иркутск. 1979. -129 c. 
3. Материалы к легенде Ботуобинской серии листов геологических карт масштаба 1:50000. / Д. В. Блажкун [и др.]. Мирный. Министерство геологии РСФСР, 1989. - 70 с.

4. Акишев, А. Н. Горно-геологические особенности коренных месторождений алмазов Якутии / А. Н. Акишев, А. В. Дроздов, В. Ф. Колганов. - Мирный. Мирнинская типография, 2013. -568 с.

5. Гидрогеология СССР. Том ХХ. / А. В. Сидоренко. Якутская АССР. Москва. Недра, 1970. - 384 с.

6. Бодунов, Е. И. Геология, гидрогеология и геохимия нефти и газа южного склона Анабарской антеклизы / Е. И. Бодунов, В. Л. Белецкий, Г. С. Фрадкин. - Якутск. ЯФ СО АН СССР, 1986.- $176 \mathrm{c}$.

7. Зуева, И. Н. Химическая структура нафтидов. ДалдыноАлакитского района. (По данным ИК- и УФ-спектроскопии) / И. Н. Зуева, Н. А. Уткина, Е. И. Бодунов // Якутск: изд. ЯФ

ФГБОУ ВО «Воронежский государственный университет»

АК «АЛРОСА» ПАО, г. Мирный

Янников Алексей Михайлович, ведущий гидрогеолог Вилюйской ГРЭ, аспирант кафедры гидрогеологии, инженерной геологии и геоэкологии

E-mail: yannikov90@mail.ru

Тел: +7 (473)2208980
CO АН CСCР. - 1987.- C. 99-110

8. Пиннекер, E. В. Рассолы Ангаро-Ленского артезианского бассейна. / Е. В. Пиннекер. - Москва. Наука, 1966. - 332 с.

9. Дроздов, А. В. Криогидрогеология алмазных месторождений Западной Якутии. / А. В. Дроздов, Н. А. Иост, В. В. Лобанов. - Иркутск. ИрГТУ, 2008. - 507 с.

10. Вожов, В. И. Гидрогеологические условия месторождений нефти и газа Сибирской платформы. / В. И. Вожов. Москва. Недра, 1987. - 204 с.

11. Изотопный состав $(\mathrm{H}, \mathrm{O}, \mathrm{Cl}, \mathrm{Sr})$ подземных рассолов Сибирской платформы / С. В. Алексеев [и др.] // Геология и геофизика.- Т. 48. - № 3. - 2007. - С. 291-304.

12. Янников, А. М. Информационный отчёт о результатах мониторинговых замеров по сети дегазационных скважин гор. -790 рудника «Интернациональный» за 2015 год. / А. М. Янников // Мирный. 2016.

\section{Voronezh State University}

AK "ALROSA" PAO

Yannikov A. M., Senior hydrogeologist Vilyui GRE, postgraduate student of the Department of hydrogeology, engineering

Geology and Geoecology Department

E-mail: yannikov90@mail.ru

Tel: +7 (473)2208980 